\title{
Bacteriocin synthesis in uropathogenic and commensal Escherichia coli: colicin E1 is a potential virulence factor
}

\author{
David Šmajs ${ }^{1 *}$, Lenka Micenková', Jan Šmarda', Martin Vrba², Alena Ševčíková ${ }^{2}$ Zuzana Vališová3 \\ Vladana Woznicová ${ }^{3}$
}

\begin{abstract}
Background: Bacteriocin production is an important characteristic of E. coli strains of human origin. To date, 26 colicin and 9 microcin types have been analyzed on a molecular level allowing molecular detection of the corresponding genes. The production incidence of 29 bacteriocin types and E. coli phylogroups were tested in a set of 361 E. coli strains isolated from human urinary tract infections (UTI) and in 411 control strains isolated from feces of patients without bacterial gut infection.

Results: Production of 17 and 20 individual bacteriocin types was found in the UTI and control strains, respectively. Microcin H47 encoding determinants were found more often among UTI strains compared to controls (37.9\% and $27.0 \%$ respectively, $\mathrm{p}=0.02$ ) and strains producing microcin $\mathrm{H} 47$ belonged predominantly to phylogroup $\mathrm{B} 2$ when compared to other bacteriocin producers (67.4\% and 36.7\%, respectively; $p<0.0001)$. Producers of 3 or more identified bacteriocin types were more common in the UTI group (20.0\% compared to $12.4 \%$ in controls, $p=0.03$ ). In the UTI strains, there was a markedly higher number of those producing colicin E1 compared to controls (22.1\% to $10.2 \%$, respectively, $\mathrm{p}=0.0008$ ). Moreover, colicin E1 production was more common in the UTI bacteriocinogenic strains with multi-producer capabilities. As shown by Southern blotting, pColE1 DNA was not recognized by the Colla probe and vice versa suggesting that PColE1 was independently associated with pColla in UTI strains.
\end{abstract}

Conclusion: E. coli strains isolated from human urinary tract infections showed increased incidence of microcin H47 and colicin E1 production, respectively. Moreover, colicin E1 itself appears to be a potentially important virulence factor of certain uropathogenic $E$. coli strains.

\section{Background}

Bacteriocins are a diverse group of gene encoded antibacterial agents including corpuscular bacteriocins, colicins, and microcins. While there is indirect evidence of presence of corpuscular bacteriocins in the genus Escherichia [1], they have not been unequivocally identified in this genus where only production of proteinaceous colicins and low molecular weight microcins has been directly demonstrated. Both colicins and microcins have a relatively narrow spectrum of activity,

\footnotetext{
* Correspondence: dsmajs@med.muni.cz

'Department of Biology, Faculty of Medicine, Masaryk University, Kamenice 5, Building A6, 62500 Brno, Czech Republic

Full list of author information is available at the end of the article
}

predominantly comprising strains of the same species (colicins) and strains of the same and related species (microcins).

Uropathogenic strains of $E$. coli (UPEC) form a subgroup of extra-intestinal pathogenic E. coli (ExPEC) strains and cause human urinary tract infections (UTI). Previous studies showed that there are several virulence factors associated with UPEC strains including adhesins, $\alpha$-hemolysin and aerobactin production, cytotoxic necrotizing factor, and microcin $\mathrm{V}$ (previously known as colicin V) [2-7]. The ColV plasmids (i.e. in present terminology microcin $\mathrm{V}$ encoding plasmids) have been found to be associated with increased pathogenicity of E. coli strains [8]. The microcin $\mathrm{V}$ encoding gene, $c v a \mathrm{C}$, has been found more frequently in cases of pyelonephritis 
compared to cases of other clinically distinct UTI infection syndromes, including cystitis and prostatitis [9], suggesting a possible role for the genes located on the microcin Vencoding plasmids in the pathogenesis of pyelonephritis. Moreover, bacteremic isolates of $E$. coli strains were more often characterized by plasmid encoded microcin $\mathrm{V}$ production [10] whereas in intestinal strains, microcin $V$ was most often chromosomally encoded. Nevertheless, there are contradictory results regarding the role of microcin $\mathrm{V}$ in bacterial virulence $[11,12]$.

Bacteriocin production is an important characteristic of E. coli and several related species in the Enterobacteriaceae family. Within the genus Escherichia, bacteriocin production is almost exclusively associated with strains of $E$. coli [13]. Moreover, there is increasing evidence indicating that bacteriocins are important elements in bacterial ecology and are linked to their possible probiotic effects [14-18]. However, the precise ecological role of bacteriocins in microbial competitions among different bacterial populations in complex bacterial communities is not yet exactly known. The variability of bacteriocin types, different modes of molecular action, varying entry routes into susceptible bacteria, and the number of additional genes present on bacteriocin genophores are just some of the obfuscating factors. To date, 26 colicin types [19-22] have been described in detail. In addition, nine microcin types have been analyzed on a molecular level allowing molecular detection of the corresponding genes [23-25]. To study the clinical and ecological importance of bacteriocin synthesis, detection of their specific types is needed due to their diversity and also due to the molecular diversity of the genes encoded on the plasmids or chromosomal regions in question. In this communication, we compare colicin and microcin types identified in two groups of E. coli strains isolated from healthy human guts and from human urinary tract infections.

\section{Results}

\section{Detection system for 23 different colicin types}

Primers shown in Additional file 1 were used to detect 23 colicin types and microcin C7. The detection system for 5 additional microcin types including $\mathrm{mB} 17, \mathrm{mH} 47$, $\mathrm{mJ} 25, \mathrm{~mL}$, and $\mathrm{mV}$ was taken from Gordon and O'Brien [26]. With the exception of cloacin DF13, pesticin I, and bacteriocin 28b, this system is able to detect all colicin types so far characterized on a molecular level. All primer pairs were tested on all 23 established colicin type producers to detect cross-reactivity with other colicin types. Cross-reactivity of the PCR amplification tests was observed in the following combinations: primers for colicin E3 gene also detected colicin E6; E6 primers also detected colicins E2, E3, E5, E8 and E9; E7 primers also detected colicin E4; E8 primers also detected colicin E7;
Ib primers also detected colicin Ia; colicin U primers also detected colicin $\mathrm{Y}$ and vice versa and primers for colicin 5 also detected colicin 10. Identification of crossreacting colicin producers therefore required sequencing of the corresponding amplicons, which was performed for all identified colicins E2-E9, Ia-Ib, U-Y, and 5-10.

\section{Bacteriocin mono- and multi-producers among the control and UTI strains}

Bacteriocin types identified in control and UTI strains are shown in Table 1 and statistically significant differences between bacteriocin producing and non-producing strains are shown in Table 2. In the UTI E. coli strains, 195 bacteriocin producing strains $(54.0 \%)$ were identified among 361 tested. This incidence was not significantly different from bacteriocin producers in the control strains (226 out of 411, 55.0\%). Mono-producers and strains producing two identifiable bacteriocin types (double producers) were similarly distributed among both UTI and control groups (mono-producers: $48.7 \%$ and $45.6 \%$, respectively; double producers: $30.1 \%$ and $28.2 \%$, respectively). Within bacteriocin monoproducers, reduced frequency of strains producing either colicin Ia or Ib was found (5.1\% and 13.7\% among UTI strains and controls, respectively, $\mathrm{p}=0.003)$. Bacterial strains with 3 or more bacteriocin encoding determinants were significantly more common in the UTI group (20.0\% compared to $12.4 \%$ in controls, $\mathrm{p}=0.03$ ). Both UTI and control strains showed a similar percentage of unidentified bacteriocin types $(6.2 \%$ and $8.8 \%$, respectively), indicating the presence of, as yet, unknown bacteriocin versions or types in E. coli strains.

\section{Bacteriocin types in the control and UTI strains}

If the number of individual bacteriocin determinants in each group of producer strains was counted irrespective of the co-produced bacteriocins, 17 and 20 types were identified among the UTI and control strains, respectively. Colicins A, D, E3, E5, E6, E8, E9, 10 and microcin B17 were not detected in either group. In addition to these, colicins E4, S4, U, 5 and microcin L were not detected in the UTI strains.

Among the UTI strains, there was a marked increase in the number of strains producing colicin E1 compared to controls $(22.1 \%$ to $10.2 \%$, respectively, $\mathrm{p}=0.0008)$. This increased incidence of colicin E1 encoding determinants was not associated with mono-producers or with double producers. However, in triple producers and multi-producers, this association was very strong compared to control strains $(14.4 \%$ and $4.0 \%$ respectively, $\mathrm{p}=0.0002$ ). Microcin $\mathrm{H} 47$ encoding determinants were found more often among UTI strains compared to controls $(37.9 \%$ and $27.0 \%$ respectively, $\mathrm{p}=0.02)$. Majority of the microcin $\mathrm{H} 47$ encoding strains were 
Table 1 List of control and UTI E. coli strains producing bacteriocins and identified colicin and microcin types

\begin{tabular}{|c|c|c|c|c|c|}
\hline \multicolumn{3}{|c|}{ Control E. coli strains } & \multicolumn{3}{|c|}{ UTI E. coli strains } \\
\hline $\begin{array}{l}\text { Identified } \\
\text { bacteriocin } \\
\text { types* }\end{array}$ & $\begin{array}{l}\text { No. of strains producing specific } \\
\text { bacteriocin types or combination } \\
\text { thereof }\end{array}$ & $\begin{array}{l}\text { Frequency among } \\
\text { producer strains } \\
\text { in } \% \\
(n=226)\end{array}$ & $\begin{array}{l}\text { Identified } \\
\text { bacteriocin } \\
\text { types }\end{array}$ & $\begin{array}{l}\text { No. of strains producing specific } \\
\text { bacteriocin types or combination } \\
\text { thereof }\end{array}$ & $\begin{array}{l}\text { Frequency among } \\
\text { producer strains } \\
\text { in \% } \\
(n=195)\end{array}$ \\
\hline $\mathrm{micH} 47$ & 47 & 20.8 & $\mathrm{micH} 47$ & 60 & 30.8 \\
\hline la & 22 & 9.7 & la, micV & 25 & 12.8 \\
\hline la, micV & 21 & 9.3 & E1, la, micV & 10 & 5.1 \\
\hline $\mathrm{lb}$ & 9 & 4.0 & la & 8 & 4.1 \\
\hline Js & 9 & 4.0 & M & 7 & 3.6 \\
\hline micV & 9 & 4.0 & micV & 5 & 2.6 \\
\hline$B, M$ & 7 & 3.1 & E1, micV & 4 & 2.1 \\
\hline $\mathrm{lb}, \mathrm{micV}$ & 6 & 2.7 & $E 1, M$ & 4 & 2.1 \\
\hline K & 4 & 1.8 & E1 & 2 & 1.0 \\
\hline la, micH47 & 4 & 1.8 & $\mathrm{lb}$ & 2 & 1.0 \\
\hline E1, la, micV & 4 & 1.8 & Js & 2 & 1.0 \\
\hline E1 & 3 & 1.3 & K & 2 & 1.0 \\
\hline M & 3 & 1.3 & E1, Js & 2 & 1.0 \\
\hline E1, la & 3 & 1.3 & E1, la, M & 2 & 1.0 \\
\hline $\mathrm{E} 1, \mathrm{lb}$ & 3 & 1.3 & B, la, M & 2 & 1.0 \\
\hline micV, micH47 & 3 & 1.3 & micV, micH47 & 2 & 1.0 \\
\hline $\mathrm{micC7}$ & 2 & 0.9 & $\begin{array}{l}\text { E1, la, } \\
\text { micH47, micV }\end{array}$ & 2 & 1.0 \\
\hline $\mathrm{E} 1, \mathrm{~K}$ & 2 & 0.9 & E2 & 1 & 0.5 \\
\hline $\mathrm{E} 1, \mathrm{M}$ & 2 & 0.9 & $B, M$ & 1 & 0.5 \\
\hline $\mathrm{B}, \mathrm{M}, \mathrm{micV}$ & 2 & 0.9 & $E 1, \mathrm{Ib}$ & 1 & 0.5 \\
\hline E4, la, micV & 2 & 0.9 & E1, E2467 & 1 & 0.5 \\
\hline la, M, micV & 2 & 0.9 & $\mathrm{E} 2, \mathrm{micH} 47$ & 1 & 0.5 \\
\hline $\begin{array}{l}\text { Ib, micH47, } \\
\text { micV }\end{array}$ & 2 & 0.9 & E2-9, la & 1 & 0.5 \\
\hline E1, la, K, micV & 2 & 0.9 & $\mathrm{E} 1, \mathrm{mic} J 25$ & 1 & 0.5 \\
\hline B & 1 & 0.4 & $\mathrm{E} 7, \mathrm{~K}$ & 1 & 0.5 \\
\hline E2 & 1 & 0.4 & $\mathrm{E} 7, \mathrm{micH} 47$ & 1 & 0.5 \\
\hline E1, micV & 1 & 0.4 & $\mathrm{la}, \mathrm{K}$ & 1 & 0.5 \\
\hline E7, lb & 1 & 0.4 & $\mathrm{la}, \mathrm{M}$ & 1 & 0.5 \\
\hline la, Js & 1 & 0.4 & la, micH47 & 1 & 0.5 \\
\hline $\mathrm{la}, \mathrm{K}$ & 1 & 0.4 & $\mathrm{la}, \mathrm{Y}$ & 1 & 0.5 \\
\hline la, S4 & 1 & 0.4 & $\mathrm{lb}, \mathrm{K}$ & 1 & 0.5 \\
\hline $\mathrm{la}, \mathrm{Y}$ & 1 & 0.4 & $\mathrm{lb}, \mathrm{micH} 47$ & 1 & 0.5 \\
\hline $\mathrm{la}, \mathrm{U}$ & 1 & 0.4 & Ib, micV & 1 & 0.5 \\
\hline $\mathrm{Ib}, \mathrm{M}$ & 1 & 0.4 & K, micH47 & 1 & 0.5 \\
\hline$J s, N$ & 1 & 0.4 & $\mathrm{M}, \mathrm{N}$ & 1 & 0.5 \\
\hline Js, S4 & 1 & 0.4 & $\mathrm{~N}, \mathrm{micV}$ & 1 & 0.5 \\
\hline Js, micV & 1 & 0.4 & $\mathrm{~B}, \mathrm{E} 1, \mathrm{M}$ & 1 & 0.5 \\
\hline $\mathrm{K}, \mathrm{micH} 47$ & 1 & 0.4 & $\mathrm{~B}, \mathrm{E} 2, \mathrm{M}$ & 1 & 0.5 \\
\hline $\mathrm{N}, \mathrm{micH} 47$ & 1 & 0.4 & $B, M, N$ & 1 & 0.5 \\
\hline $\mathrm{N}, \mathrm{micV}$ & 1 & 0.4 & $\mathrm{E} 1, \mathrm{Ib}, \mathrm{micC} 7$ & 1 & 0.5 \\
\hline S4, micC7 & 1 & 0.4 & $\begin{array}{l}\text { E1, micC7, } \\
\text { micH47 }\end{array}$ & 1 & 0.5 \\
\hline $\begin{array}{l}\text { micC7, } \\
\text { micH47 }\end{array}$ & 1 & 0.4 & $\mathrm{la}, \mathrm{K}, \mathrm{micV}$ & 1 & 0.5 \\
\hline micH47, micL & 1 & 0.4 & $\begin{array}{l}\text { la, micC7, } \\
\mathrm{micV}\end{array}$ & 1 & 0.5 \\
\hline$B, I b, M$ & 1 & 0.4 & la, N, micV & 1 & 0.5 \\
\hline
\end{tabular}


Table 1 List of control and UTI E. coli strains producing bacteriocins and identified colicin and microcin types (Continued)

\begin{tabular}{|c|c|c|c|c|c|}
\hline $\mathrm{E} 1, \mathrm{E} 4, \mathrm{~K}$ & 1 & 0.4 & $\mathrm{lb}, \mathrm{N}, \mathrm{micV}$ & 1 & 0.5 \\
\hline la, Js, micV & 1 & 0.4 & $B, E 1, I b, M$ & 1 & 0.5 \\
\hline la, E2-9, micV & 1 & 0.4 & $\begin{array}{l}\text { B, E1, M, } \\
\text { micV }\end{array}$ & 1 & 0.5 \\
\hline la, K, micV & 1 & 0.4 & $\begin{array}{l}\text { E1, E2, K, } \\
\text { micV }\end{array}$ & 1 & 0.5 \\
\hline la, 5, micV & 1 & 0.4 & $\begin{array}{l}\text { E1, E3589, la, } \\
\text { micV }\end{array}$ & 1 & 0.5 \\
\hline B, la, M, micV & 1 & 0.4 & E1, la, K, micV & 1 & 0.5 \\
\hline $\mathrm{B}, \mathrm{Ib}, \mathrm{M}, \mathrm{micV}$ & 1 & 0.4 & $\begin{array}{l}\mathrm{E} 1, \mathrm{Js}, \mathrm{N} \\
\mathrm{micV}\end{array}$ & 1 & 0.5 \\
\hline $\mathrm{B}, \mathrm{M}, \mathrm{E} 2, \mathrm{micV}$ & 1 & 0.4 & $\begin{array}{l}\text { E1, K, micV, } \\
\text { micC7 }\end{array}$ & 1 & 0.5 \\
\hline $\begin{array}{l}\text { E1, la, M, } \\
\text { micV }\end{array}$ & 1 & 0.4 & $\begin{array}{l}\text { la, K, micH47, } \\
\text { micV }\end{array}$ & 1 & 0.5 \\
\hline $\mathrm{E} 1, \mathrm{Ib}, \mathrm{N}, \mathrm{micV}$ & 1 & 0.4 & $\begin{array}{l}\text { B, M, micH47, } \\
\text { micV }\end{array}$ & 1 & 0.5 \\
\hline$B, M, N$, micV & 1 & 0.4 & $\begin{array}{l}\text { E1, E7, } \\
\text { micH47, micV }\end{array}$ & 1 & 0.5 \\
\hline $\begin{array}{l}\text { B, M, micH47, } \\
\text { micV }\end{array}$ & 1 & 0.4 & $\begin{array}{l}\text { E1, la, } \\
\text { micH47, micV }\end{array}$ & 1 & 0.5 \\
\hline $\begin{array}{l}\text { la, micC7, } \\
\text { micJ25, micV }\end{array}$ & 1 & 0.4 & $\begin{array}{l}\text { B, E1, la, M, } \\
\text { micV }\end{array}$ & 1 & 0.5 \\
\hline \multirow[t]{3}{*}{ unidentified } & 20 & 8.8 & $\begin{array}{l}\text { E1, E7, la, K, } \\
\text { micV }\end{array}$ & 1 & 0.5 \\
\hline & & & $\begin{array}{l}\mathrm{B}, \mathrm{E} 2, \mathrm{~K}, \mathrm{M}, \mathrm{N}, \\
\mathrm{micV}\end{array}$ & 1 & 0.5 \\
\hline & & & unidentified & 12 & 6.2 \\
\hline
\end{tabular}

*colicin types are given without prefix, mic stands for microcin

mono-producers with higher incidence among UTI strains compared to controls $(30.8 \%$ and $20.8 \%$ respectively, $\mathrm{p}=0.02$ ).

\section{E. coli phylogroups and colicin production}

All investigated strains were phylogenetically analyzed using triplex PCR [27]. There was a marked increase of the B2 genotype in the UTI group compared to controls $(59.0 \%$ and $42.1 \%$, respectively; $\mathrm{p}<0.0001)$, and a decreased incidence of the A genotype $(19.4 \%$ and $31.1 \%$, respectively; $\mathrm{p}=0.0002$ ). Additionally, a higher incidence of the B2 phylogroup was found in the UTI strains of male origin ( $74.1 \%$, data not shown) compared with UTI strains of female origin $(54.4 \%, \mathrm{p}=0.001)$. Distribution of producer and non-producer strains among E. coli genotypes is shown in Table 3 . In the $E$. coli phylogroup B1, the incidence of bacteriocin producing strains was significantly lower among UTI strains when compared to controls.

The incidence of colicinogenic strains among all strains including both UTI and control strains was higher in the phylogroup A $(56.3 \%$ and $39.0 \%$, respectively; $\mathrm{p}=0.0007)$ and $\mathrm{D}(53.4 \%$ and $39.0 \%$, respectively; $\mathrm{p}=0.009$ ) when compared to B2 (data not shown). In contrast, group B2 showed higher incidence of microcin-encoding strains when compared to strains of group A $(56.0 \%$ and $37.7 \%$, respectively; $\mathrm{p}=0.0003)$ and $\mathrm{D}$ (56.0\% and $39.0 \%$, respectively; $\mathrm{p}=0.002)$. Producers of microcin $\mathrm{H} 47$ belonged more frequently to group B2 (data not shown) when compared to other bacteriocin producers $(67.2 \%$ and $36.9 \%$, respectively; $\mathrm{p}<0.0001)$ and less frequently to groups A $(10.4 \%$ and $35.5 \%$, respectively; $\mathrm{p}<0.0001)$ and $\mathrm{B} 1(0.7 \%$ and $4.5 \%$, respectively; $\mathrm{p}<0.04$ ).

\section{ColE1 plasmids in multi-producer strains}

Strains producing the combination of colicins Ia and E1 were more common in the UTI group compared to controls $(9.7 \%$ and $4.4 \%$, respectively, $\mathrm{p}=0.03)$ as well as strains producing bacteriocins Ia, E1 and $\mathrm{mV}(8.7 \%$ and $3.1 \%$, respectively, $\mathrm{p}=0.01$ ). To test whether these producers synthesizing colicin E1 contain regular low molecular weight pColE1 plasmids or only colicin E1-encoding determinants located on larger plasmids, the plasmid size of 12 colicin E1 producing strains, selected at random, was estimated using the Southern blotting procedure with 
Table 2 Statistically significant differences in the incidence of bacteriocin encoding determinants among UTI and control $E$. coli strains

\begin{tabular}{|c|c|c|c|}
\hline Types of bacteriocin producers & $\begin{array}{l}\text { No. of UTI } \\
\text { bacteriocin } \\
\text { producers } \\
(\%)\end{array}$ & $\begin{array}{l}\text { No. of control bacteriocin } \\
\text { producers } \\
\text { (\%) }\end{array}$ & $\begin{array}{l}\text { Statistical } \\
\text { significance } \\
\text { of the difference* }\end{array}$ \\
\hline microcin $\mathrm{H} 47$ producers & $74(37.9)$ & $61(27.0)$ & $p=0.02$ \\
\hline producers of colicins la and Ib among mono-producers & $10(5.1)$ & $31(13.7)$ & $p=0.003$ \\
\hline producers of three or more bacteriocins & $39(20.0)$ & $28(12.4)$ & $p=0.03$ \\
\hline colicin E1 producers & $43(22.1)$ & $23(10.2)$ & $p=0.0008$ \\
\hline $\begin{array}{l}\text { producers of colicin E1 among bacteriocin triple- and multi- } \\
\text { producers }\end{array}$ & $28(14.4)$ & $9(4.0)$ & $p=0.0002$ \\
\hline bacteriocin E1 and la producers & $19(9.7)$ & $10(4.4)$ & $p=0.03$ \\
\hline bacteriocin $\mathrm{E} 1$, la, and $\mathrm{mV}$ producers & $17(8.7)$ & $7(3.1)$ & $p=0.01$ \\
\hline
\end{tabular}

${ }^{*}$ statistical methods derived from the binomial distribution were used (see Methods)

colicin E1 and colicin Ia probes (Figure 1). Most of these strains synthesized also colicin Ia and microcin V. As shown by Jeziorowski and Gordon [28], when colicin Ia and microcin $\mathrm{V}$ co-occur, they are encoded on the same conjugative plasmid as a result of integration of microcin $\mathrm{V}$ operon and several other genes into the pColIa plasmid. As shown by Southern blot analysis, all tested colicin E1 producers had low molecular weight plasmid DNA recognized by colicin E1 probe with size ranging from 6.8 to 10 kb (for 6 plasmid samples see Figure 1). To verify the pColE1 plasmid sizes, XL-PCR approach was used to amplify the entire pColE1 using complementary primers recognizing colicin E1 operon. In 10 out 12 samples, a successful DNA amplification resulted in PCR product size ranging between 7.0 - $10 \mathrm{~kb}$ (data not shown). The colicin Ia probe hybridized with a higher molecular weight plasmid DNA (Figure 1) indicating that these strains harbor colicin E1 plasmids together with an additional bacteriocin-encoding plasmid.

\section{Discussion}

A detection system for 23 different colicin types was designed and tested. Together with previously published microcin primer set [26], most of the well characterized bacteriocins in the genus Escherichia can be identified. Gordon and O'Brien [26] found 102 bacteriocin producing strains among 266 (38\%) human E. coli strains, whereas in our study, $55 \%(226 / 411)$ of $E$. coli control strains (of similar human origin) were bacteriocin producers. Gordon and O'Brien detected eleven colicin types and seven microcin types. With the exception of microcin $\mathrm{M}$ (which co-occurs with microcin $\mathrm{H} 47$ ), all

Table 3 Incidence of bacteriocin producing and non-producing strains among UTI and control strains in $E$. coli phylogroups

\begin{tabular}{|c|c|c|c|}
\hline \multicolumn{4}{|c|}{ E. coli phylogroup A } \\
\hline & UTI $(n=128)$ & Control $(n=70)$ & statistical significance between UTI and control* \\
\hline Producers & $79(61.7 \%)$ & $37(52.9 \%)$ & $-* *$ \\
\hline Non-producers & 49 (38.3\%) & $33(47.1 \%)$ & \\
\hline \multicolumn{4}{|c|}{ E. coli phylogroup B1 } \\
\hline & UTI $(n=25)$ & Control $(n=11)$ & statistical significance between UTI and control* \\
\hline Producers & $7(28 \%)$ & $7(63.6 \%)$ & $p=0.04$ \\
\hline Non-producers & $18(72 \%)$ & $4(36.4 \%)$ & \\
\hline \multicolumn{4}{|c|}{ E. coli phylogroup B2 } \\
\hline & UTI $(n=173)$ & Control $(n=213)$ & statistical significance between UTI and control* \\
\hline Producers & $86(49.7 \%)$ & $110(51.6 \%)$ & $-* *$ \\
\hline Non-producers & $87(50.3 \%)$ & $103(48.4 \%)$ & \\
\hline \multicolumn{4}{|c|}{ E. coli phylogroup D } \\
\hline & UTI $(n=85)$ & Control $(n=67)$ & statistical significance between UTI and control* \\
\hline Producers & $54(63.5 \%)$ & $41(61.2 \%)$ & $-* *$ \\
\hline Non-producers & $31(36.5 \%)$ & $26(38.8 \%)$ & \\
\hline
\end{tabular}

*statistical methods derived from the binomial distribution were used (see Methods, $\chi^{2}=3.41, p=0.05$ )

**not statistically significant 


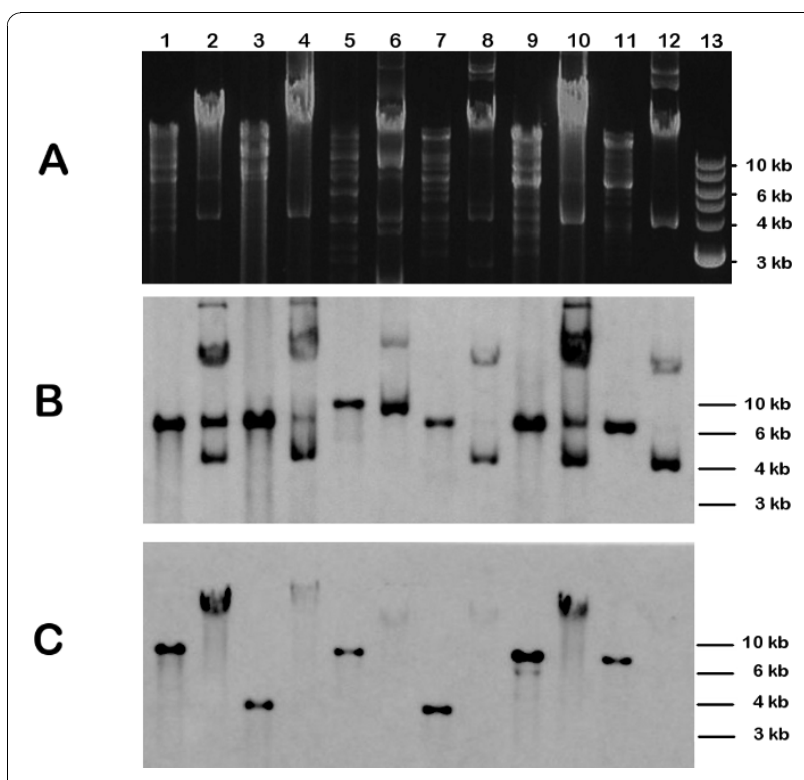

Figure 1 Detection of DNA encoding colicins E1 and la in 6 plasmid DNA samples (out of 12 randomly picked and analyzed colicin E1 producers). Panel A: an agarose gel with total plasmid DNA stained with ethidium bromide; panel B: Southern blot analysis of the same plasmid DNA samples with colicin E1 probe; panel C: Southern blot analysis with colicin la probe. The $1 \mathrm{~kb}$ DNA ladder (New England Biolabs, Ipswitch, MA) was used as the DNA marker (panel A, lane 13). Lanes 1 and 2, plasmid DNA isolated of strain B399 (digested with EcoRI and undigested, respectively). Lanes 3 and 4, strain B954 (producer of colicins E1, la, and microcin V); lanes 5 and 6, strain B961; lanes 7 and 8, strain B2041; lanes 9 and 10, strain B953; lanes 11 and 12, strain B830. Strains B399, B954, B2041 and B830 were all producers of colicins E1, la, and microcin V. Strain B961 produced colicins E1, la, E7, K and microcin V. Strain B953 produced colicins E1, la, and microcins $V$ and $H 47$. Please note that patterns of undigested plasmid DNA were different in panel $B$ and $C$, respectively, indicating that colicin la and E1 genes are located on separate plasmids.

types used in the published study [26] were tested in the present work. Since the identification scheme of bacteriocin producers, including indicator strains and cultivation conditions, differed in both studies, it is likely that the $17 \%$ difference reflects the primary identification of producer strains. In our study, $6.2 \%$ and $8.8 \%$ of strains in both control and UTI strains, respectively, produced unidentified bacteriocins. Appearance of inhibition zones, inducibility with mitomycin $\mathrm{C}$ and sensitivity to trypsin suggested that both colicin and microcin types could be expected among untyped producer strains. Some of these strains possibly produce already known, though untested, colicin and microcin types (cloacin DF13, pesticin and bacteriocin 28b, and microcins $M$, E492, 24, D93). Despite this fact, untyped bacteriocin producers represent an interesting set of $E$. coli strains needing further bacteriocin research.
Both our groups of control strains (taken from two hospitals) were nearly equal in the incidence of bacteriocin types. Since the tributary areas of both hospitals overlap, similarity in incidence of identified bacteriocin types likely reflects the fact that all samples were taken from persons living in the same area of South Moravia, Czech Republic.

No statistically important difference was found in the incidence of bacteriocin producers among UTI strains (54.0\% of producer strains) compared to control strains (55.0\%). This observation may reflect the fact that most uropathogenic strains originate in the human gut [29]. Investigation of 568 clinical isolates of uropathogenic strains of E. coli collected in New Zealand [30] revealed lower incidence of bacteriocin producers $(42.6 \%)$; an even lower incidence (32.3\%) was found among 440 E. coli UTI strains tested in 2001 in the Czech Republic [1]. In the latter case, only "rich media" were used for identification of bacteriocin producers, which could result in lower microcin detection in both UTI and control strains (34.8\% of control strains were found to be colicinogenic in our study).

Commensal strains of E. coli belong mainly to phylogroups A and B1 whereas the group B2 contains highly virulent $E$. coli strains [31]. Virulent $E$. coli strains are also often found in group D. E. coli strains in groups B2 and D have the largest genomes [32]. However, there is no exclusive link between $E$. coli groups B2 and D and the ability to cause infection since $E$. coli strains belonging to all groups can cause infection under specific conditions. The observed higher incidence of $E$. coli group B2 among UTI strains, relative to group A, is therefore not surprising. We found that microcin $\mathrm{H} 47$ encoding genes are present predominantly in E. coli phylogenetic group B2. Since microcin $\mathrm{H} 47$ encoding determinants are localized on a bacterial chromosome [33], microcin H47 (and microcin M) genes appears to be often part of genetic elements specific for group B2 [27]. Our findings also suggest that colicin production is principally associated with $E$. coli phylogroup A (and to lesser extent with group D) and not with genotype B2, where microcin producers are more common. As suggested in previous publications [13,34], our results support the model where the colicin producer phenotype, within the Enterobacteriaceae family, belongs primarily to commensal intestinal $E$. coli strains.

We found a statistically significant increase in UTI strains producing colicin E1 compared to controls (22.1\% and $10.2 \%$, respectively). There was an especially strong association between triple and multiple bacteriocin producers and colicin E1 production - with p-values lower than 0.0005 . In a previously published paper [35], ColE1-like plasmids were frequently found among uropathogenic strains of E. coli (UPEC). However, no 
control group was tested to identify the statistical significance of this finding. Among 89 identified bacteriocin producers, $43 \%$ were positive for mobA-, rom- and RNAII-specific sequences [35]; also, since other colicin plasmids may contain the same or highly similar sequences to pColE1 (e.g. pColU) [36], the exact extent of the colicin E1 producing subset is unknown. Based on frequency of incidences of colicin E1 production in our study, the majority of producer strains described by Rijavec et al. [35] containing ColE1-like sequences were probably strains harboring pColE1.

In the group of UTI strains, lower bacteriocin diversity and an increased number of triple and multiple producers were identified. The bacteriocin multi-producer phenotype of UTI strains was predicted as one possible explanation of unidentified colicin types in a previous study [30]. In general, the multi-producer phenotypes require: (i) efficient genetic transfer within the bacterial community, (ii) low habitat heterogeneity to ensure effective negative selection of sensitive bacteria, and (iii) relatively low bacteriocin biosynthesis costs. As experimentally shown by Braude and Siemienski [37] in rats, the first two conditions apply to urinary tract infections suggesting that the multi-producer phenotype is favored among UPEC strains. Besides reduced habitat heterogeneity of the urinary tract compared to the human colon, the multi-producer strains could be more frequently found in UTI infections because of additional virulence factors associated with bacteriocin encoding determinants. Although the first explanation may also apply to the higher incidence of colicin E1 plasmids in the UTI, it is unlikely that there are any additional virulence determinants on pColE1 plasmids besides the colicin E1 determinant itself. The size of previously published ColE1 plasmids varied from $5.2 \mathrm{~kb}$ [14] to $9 \mathrm{~kb}$ in the E. fergusonii EF3 strain [38] and contained regions important for plasmid replication, mobilization, and for colicin synthesis. No known virulence determinants have been identified on these plasmids. As shown previously, colicin E1 can kill both normal and cancer eukaryotic cells and this effect has been shown to be cell-specific $[39,40]$. The toxic effect of colicin E1 on uroepithelial cells could be one of the potential virulence mechanisms found in UPEC strains.

When compared to controls, producer strains with the combination of colicins Ia, E1, and $\mathrm{mV}$ were more common in the UTI group. As shown by Jeziorowski and Gordon [28], when colicin Ia and microcin V occur together, they are encoded on the same conjugative plasmid as a result of integration of the microcin $\mathrm{V}$ operon and several other genes into the pColIa plasmid. Therefore we tested whether similar integration of colicin E1 genes into the pColla could explain the observed association of colicin E1 and colicin Ia synthesis. Among the 12 randomly picked colicin E1-synthesizing multiproducers, all strains contained pColE1 DNA that was not recognized by the probe complementary to the colicin Ia-encoding DNA and vice versa, suggesting that pColE1 was independently co-associated with pColla in UTI strains. Moreover, pColE1 sizes were similar to those published previously $(5.2 \mathrm{~kb},[14]$; $9 \mathrm{~kb},[38])$ indicating that the pColE1 DNA is unlikely to encode any known virulence factor. This finding suggests that colicin E1 itself is a potential virulence factor of certain uropathogenic strains of $E$. coli. However, it is possible that strains carrying colicin E1 genes differ in their genetic content and contain elements promoting their urovirulence. Since it is known that colicin E1 is independently associated with $E$. coli phylogroups [26], the first explanation appears more probable.

\section{Conclusions}

E. coli strains isolated from human urinary tract infections showed increased incidence of microcin $\mathrm{H} 47$ and colicin E1 production, respectively, and belonged more often to phylogroup B2 when compared to control E. coli strains. In the UTI group, producers of 3 or more identified bacteriocin types were more common. Moreover, the incidence of colicin E1 production was high in the UTI multi-producer bacteriocinogenic strains. Unlike colicin Ia- and microcin V-encoding determinants [28], pColE1 was independently associated with pColIa in the UTI strains. Thus, colicin E1 itself appears to be a potentially important virulence factor of certain uropathogenic strains of $E$. coli.

\section{Methods}

\section{Bacterial strains}

Altogether, 772 human E. coli strains were isolated between May 2007 and June 2009, from both male and female patients. Five hundred and fifty-nine strains were collected from the Faculty Hospital Bohunice, Brno, CZ, including $361 \mathrm{E}$. coli strains isolated from urinary tract infections (UTI) and 198 E. coli strains isolated from feces of patients without bacterial gut infections (control commensal strains). Additional 213 strains of E. coli (isolated from feces of patients without bacterial gut infections) were collected from the St. Ann's Faculty Hospital, Brno, CZ. Out of 411 E. coli control strains (190 of male and 221 of female origin), only 92 (22.4\%) stemmed from patients with primary diagnoses related to the gastrointestinal system (e.g. pancreatitis, dyspepsia etc.) and none were isolated from cases with detectable bacterial intestinal infection. Since no statistically significant differences in the incidence of producer strains or the incidence of individual bacteriocin types between control groups from both hospitals were found, strains from both groups were merged and treated as a single 
group. UTI strains were isolated from 85 males and 276 females. Bacterial identification of E. coli was performed using a set of biochemical reactions (ENTEROtest 16, PLIVA-Lachema Diagnostika, Czech Republic). All donors of investigated strains were Caucasians living in the South Moravia region of the Czech Republic. For each sample, the primary diagnosis of the source patient was established by an experienced clinician.

A described set of $E$. coli indicator strains was used to identify the colicin and microcin types produced: $E$. coli K12-Row, C6 ( $\varphi)$, B1, P400, and Shigella sonnei 17 [1]; additionally, one recently verified indicator strain, $E$. coli S40, was also used [41]. Together, these indicator strains are capable of detecting all known colicin types including colicin L (P400) and colicin Js (S.s. 17).

Control bacterial producers encoding different colicin types were taken from laboratory stock and comprised $E$. coli BZB2101pColA - CA31, BZB2102 pColB - K260, BZB2103 pColD - CA23, BZB2107 pColE4 - CT9, BZB2108 pColE5 - 099, BZB2150 pColE6 - CT14, BZB2120 pColE7 - K317, BZB2279 pColIa - CA53, BZB2202 ColIb - P9, BZB2116 pColK - K235, PAP1 pColM - BZBNC22, BZB2123 pColN - 284 (original source: A. P. Pugsley), E. coli 189BM pColE2 - P9 (B. A. D. Stocker), E. coli 385/80 pColE1, pColV (H. Lhotová), E. coli 185M4 pColE3 - CA38 (P. Fredericq), E. coli W3110 pColE8, W3110 pColE9 (J. R. James), E. coli K-12 pColS4 (D. Šmajs), S. boydii M592 (serovar 8) pColU (V. Horák), E. coli K339 pColY (D. Friedman), Shigella sonnei (colicinotype 7) pColJs (J. Šmarda), E. coli pCol5 and E. coli pCol10 (H. Pilsl). As microcin control producers, the following bacterial strains were used: E. coli 449/82 pColX (microcin B17); E. coli 313/66 pColG (microcin H47); E. coli 363/79 pColV (microcin V, original source: H. Lhotová); E. coli TOP10F' pDS601 (microcin C7); E. coli D55/ 1 (microcin J25); E. coli B1239 (microcin L, D. Šmajs).

\section{Cultivation conditions}

The ability to produce bacteriocins of all the strains was tested in parallel on 4 different agar plates containing (i) TY medium, (ii) nutrient broth, (iii) TY medium supplemented with mitomycin C, and (iv) TY medium supplemented with trypsin. The rich TY medium consisted of yeast extract (Hi-Media, Mumbai, India) $5 \mathrm{gl}^{-1}$, tryptone (Hi-Media) $8 \mathrm{gl}^{-1}$, sodium chloride $5 \mathrm{gl}^{-1}$; the TY agar consisted of a base layer (1.5\%, w/v, solid agar) and a top layer $(0.7 \%, \mathrm{w} / \mathrm{v}$, soft agar). As a relatively unenriched medium, a Difco ${ }^{\text {tw }}$ nutrient broth (Difco Laboratories, Sparks, MD) $8 \mathrm{gl}^{-1}, \mathrm{NaCl} 5 \mathrm{gl}^{-1}$, was used for $1.5 \%(\mathrm{w} / \mathrm{v})$ agar plates. For induction of colicin production, the base agar layer was supplemented with $0.01 \%(\mathrm{w} / \mathrm{v})$ mitomycin C. To test protease sensitivity of the inhibitive agents, $0.1 \%(\mathrm{w} / \mathrm{v})$ trypsin was added to the base layer of agar.

\section{Detection of colicin producers}

The agar plates were inoculated by needle stab with fresh broth cultures and the plates were incubated at $37^{\circ} \mathrm{C}$ for 48 hours. The bacteria were then killed using chloroform vapors and each plate was then overlaid with a thin layer of soft agar containing $10^{7}$ cells ml$^{-1}$ of an indicator strain. The plates were then incubated at $37^{\circ} \mathrm{C}$ overnight. All $772 \mathrm{E}$. coli strains of clinical origin were tested on four parallel plates against all 6 indicators, i.e. each strain underwent 24 individual tests.

\section{Identification of colicin and microcin types and determination of $E$. coli phylogenetic group}

Identification of individual colicin types (colicins A, B, D, E1-E9, Ia, Ib, Js, K, M, N, S4, U, Y, 5 and 10) was performed using PCR with primers designed using the Primer3 program [42] or with previously published primers [26]. The list of primer pairs and the corresponding length of PCR products are listed in Additional file 1. Total bacterial DNA was isolated using DNAzol (Invitrogen, Carlsbad, CA) reagent according to the manufacturer's protocol. After 100-fold dilution, this DNA was used as a template for PCR reactions. Alternatively, all producer strains were tested with colony PCR. A bacterial colony was picked with a sterile inoculation loop and resuspended in $100 \mu \mathrm{l}$ of autoclaved water. For each individual PCR reaction, $1 \mu \mathrm{l}$ of cell suspension was added to the reaction. The PCR detection protocol was as follows: $94^{\circ} \mathrm{C}$ (2 minutes); $94^{\circ} \mathrm{C}$ (30 seconds), $60^{\circ} \mathrm{C}$ (30 seconds), $72^{\circ} \mathrm{C}$ ( 1 minute), 30 cycles; $72^{\circ} \mathrm{C}$ (7 minutes). For DNA amplification directly performed from lysed whole cells (colony PCR), the initial step was extended to 5 minutes $\left(94^{\circ} \mathrm{C}, 5\right.$ minutes). All primers detecting colicins were tested against all type producers to reveal potential cross-reactivity of sequentially similar colicin genes. The primer sequences for PCR detection of microcins B17, H47, J25, L, and V, respectively, were taken from previously published paper [26]. With the exception of microcin $M$, all bacteriocin genes detected in the study performed by Gordon and O'Brien [26] were analyzed in this work. Moreover, 12 additional bacteriocin genes were detected by us. PCR products resulting from detection of sequentially related colicin genes (colicins E2-E9, Ia-Ib, U-Y, and 5-10, respectively) were subjected to dideoxyterminator sequencing using amplification primers. Because of sensitivity of microcin $\mathrm{H} 47$ to chloroform vapours, all investigated strains were tested for the presence of microcin H47-encoding genes. Sequence analysis was performed using Lasergene software (DNASTAR, Inc., Madison, WI). The phylogenetic group of each $E$. coli strain was determined using the triplex PCR protocol described previously [27]. 


\section{Statistical analyses}

Statistical significance of the incidence of genotypes and colicin or microcin types, in both strain groups, was performed by applying standard methods derived from the binomial distribution, including the two-tailed test. STATISTICA version 8.0 (StatSoft, Tulsa, OK, USA) was used for statistical calculations. Alternatively, an interactive calculation tool for chi-square tests of "goodness of fit" and independence was used for the calculation of statistical significance of obtained results [43].

\section{Southern blot analyses and XL-PCR}

The total plasmid DNA of selected colicin producers were isolated using QIAprep Spin Miniprep Kit and QIAGEN Plasmid Midi Kit (Qiagen, Hilden, Germany), respectively. During isolation of plasmid DNA, manufacturer's recommendations were followed. The plasmid DNA was digested with the EcoRI restriction endonuclease (New England Biolabs, Ipswitch, MA) and the undigested and digested total plasmid DNA was transferred to the Hybond-XL membrane by a standard capillary method (Amersham, Buckinghamshire, UK). The colicin E1 and Ia probes used in Southern blot analysis were amplified from the control producer strains with primers used for detection of colicin genes (Additional file 1). The probes were labelled with the Gene Images AlkPhos Direct Labelling and Detection System (Amersham) and the labelled hybridized probes were detected with the ECF chemifluorescent substrate and the Typhoon imager (Amersham) according to the manufacturer's recommendations.

The GeneAmp ${ }^{\circ}$ XL PCR Kit (Roche Molecular Systems, Branchburg, NJ, USA) was used for amplification of pColE1 plasmid DNA using pColE1-seq1 (5' GCCGATCGTGATGCTATTTT - 3') and pColE1-seq2 (5' - AAAATAGCATCACGATCGGC - 3') complementary primers recognizing colicin E1 operon.

\section{Additional material}

Additional file 1: DNA Primers used for PCR detection of colicin and microcin encoding genes.

\section{Acknowledgements}

This work was supported by a grant from the Ministry of Health of the Czech Republic (NS9665-4/2008) to D.S. and by institutional support from the Czech Republic (MSM0021622415).

\section{Author details}

${ }^{1}$ Department of Biology, Faculty of Medicine, Masaryk University, Kamenice 5, Building A6, 62500 Brno, Czech Republic. ${ }^{2}$ Department of Clinical Microbiology, Faculty Hospital Brno, Jihlavská 20, 62500 Brno, Czech Republic. ${ }^{3}$ Department of Medical Microbiology, Faculty of Medicine, Masaryk University, Pekařská 53, 65691 Brno, Czech Republic.

\section{Authors' contributions}

DS designed the study and wrote the manuscript. LM and JS performed bacteriocin testing of $E$. coli strains and analyzed the obtained data. MV, AS, ZV and WW contributed to isolations and characterizations of the bacterial strains and gathered data. All authors read and approved the final manuscript.

Received: 16 June 2010 Accepted: 15 November 2010

Published: 15 November 2010

References

1. Šmarda J, Obdržálek V: Incidence of colicinogenic strains among human Escherichia coli. J Basic Microbiol 2001, 41:367-374.

2. Blanco JM, Alonso P, Gonzalez EA, Blanco M, Garabal Jl: Virulence factors of bacteraemic Escherichia coli with particular reference to production of cytotoxic necrotising factor (CNF) by P-fimbriate strains. J Med Microbiol 1990, 31:175-183.

3. Hughes C, Hacker J, Roberts A, Goebel W: Hemolysin production as a virulence marker in symptomatic and asymptomatic urinary tract infections caused by Escherichia coli. Infect Immun 1983, 39:546-551.

4. Johnson JR, Moseley SL, Roberts PL, Stamm WE: Aerobactin and other virulence factor genes among strains of Escherichia coli causing urosepsis: association with patient characteristics. Infect Immun 1988, 56:405412.

5. Kaijser B: Immunology of Escherichia coli: $\mathrm{K}$ antigen and its relation to urinary-tract infection. J Infect Dis 1973, 127:670-677.

6. Svanborg Edén C, Eriksson B, Hanson LA: Adhesion of Eschericha coli to human uroepithelial cells in vitro. Infect Immun 1977, 18:767-774.

7. Williams PH: Novel iron uptake system specified by ColV plasmids: an important component in the virulence of invasive strains of Escherichia coli. Infect Immun 1979, 26:925-932.

8. Smith HW, Huggins MB: Further observations on the association of the colicine $\mathrm{V}$ plasmid of Escherichia coli with pathogenicity and with survival in the alimentary tract. J Gen Microbiol 1976, 92:335-350.

9. Johnson JR, Kuskowski MA, Gajewski A, Soto S, Horcajada JP, Jimenez de Anta MT, Vila J: Extended virulence genotypes and phylogenetic background of Escherichia coli isolates from patients with cystitis, pyelonephritis, or prostatitis. J Infect Dis 2005, 191:46-50.

10. Fernandez-Beros ME, Kissel V, Lior H, Cabello FC: Virulence-related genes in ColV plasmids of Escherichia coli isolated from human blood and intestines. J Clin Microbiol 1990, 28:742-746.

11. Quackenbush RL, Falkow S: Relationship between colicin V activity and virulence in Escherichia coli. Infect Immun 1979, 24:562-564.

12. Wooley RE, Nolan LK, Brown J, Gibbs PS, Bounous DI: Phenotypic expression of recombinant plasmids pKT107 and pHK11 in an avirulent avian Escherichia coli. Avian Dis 1994, 38:127-134.

13. Šmarda J, Šmajs D, Lhotová H: Three recently acknowledged Escherichia species strikingly differ in the incidence of bacteriocinogenic and lysogenic strains. J Basic Microbiol 2002, 42:429-433.

14. Cursino L, Šmajs D, Šmarda J, Nardi RM, Nicoli JR, Chartone-Souza E, Nascimento AM: Exoproducts of the Escherichia coli strain $\mathrm{H} 22$ inhibiting some enteric pathogens both in vitro and in vivo. J Appl Microbiol 2006, 100:821-829.

15. Gillor O, Giladi I, Riley MA: Persistence of colicinogenic Escherichia coli in the mouse gastrointestinal tract. BMC Microbiol 2009, 12:165.

16. Lodinová-Žádníková R, Bartáková Z, Tlaskalová H: The effect of oral colonization by non-pathogenic $E$. coli on the immune response in neonates and possibilities of its use in the prevention of nosocomial infections in children at risk. Česk Epidemiol Mikrobiol Imunol 1992, 42:126-132.

17. Montalto M, Arancio F, Izzi D, Cuoco L, Curigliano V, Manna R, Gasbarrini G: Probiotics: history, definition, requirements and possible therapeutic applications. Ann Ital Med Int 2002, 17:157-165.

18. Šmajs $D$, Strouhal $M$, Matějková $P$, Čejková $D$, Cursino L, Chartone-Souza $E$ Šmarda J, Nascimento AM: Complete sequence of low-copy-number plasmid MccC7-H22 of probiotic Escherichia coli $\mathrm{H} 22$ and the prevalence of mcc genes among human E. coli. Plasmid 2008, 59:1-10.

19. Šmarda J, Šmajs D: Colicins-exocellular lethal proteins of Escherichia coli. Folia Microbiol (Praha) 1998, 43:563-582. 
20. Pilsl H, Šmajs D, Braun V: Characterization of colicin S4 and its receptor, OmpW, a minor protein of the Escherichia coli outer membrane. J Bacteriol 1999, 181:3578-3581.

21. Riley MA, Cadavid L, Collett MS, Neely MN, Adams MD, Phillips CM, Neel JV, Friedman D: The newly characterized colicin $Y$ provides evidence of positive selection in pore-former colicin diversification. Microbiology 2000, 146:1671-1677.

22. Šmajs D, Weinstock GM: Genetic organization of plasmid ColJs, encoding colicin Js activity, immunity, and release genes. J Bacteriol 2001 183:3949-3957.

23. Braun VS, Patzer I, Hantke K: Ton-dependent colicins and microcins: modular design and evolution. Biochimie 2002, 84:365-380.

24. Destoumieux-Garzón D, Peduzzi J, Rebuffat S: Focus on modified microcins: structural features and mechanisms of action. Biochimie 2002, 84:511-519.

25. Severinov K, Semenova E, Kazakov A, Kazakov T, Gelfand MS: Lowmolecular-weight post-translationally modified microcins. Mol Microbiol 2007, 65:1380-1394.

26. Gordon DM, O'Brien CL: Bacteriocin diversity and the frequency of multiple bacteriocin production in Escherichia coli. Microbiology 2006, 152:3239-3244.

27. Clermont O, Bonacorsi S, Bingen E: Rapid and simple determination of the Escherichia coli phylogenetic group. Appl Environ Microbiol 2000, 66:4555-4558.

28. Jeziorowski A, Gordon DM: Evolution of microcin V and colicin la plasmids in Escherichia coli. J Bacteriol 2007, 189:7045-7052.

29. Brumfitt W, Gargan RS, Hamilton-Miller JM: Periurethral enterobacterial carriage preceding urinary infection. Lancet 1987, 11:824-826.

30. O'Brien GJ, Chambers ST, Peddie B, Mahanty HK: The association between colicinogenicity and pathogenesis among uropathogenic isolates of Escherichia coli. Microb Pathog 1996, 20:185-190

31. Picard B, Garcia JS, Gouriou S, Duriez P, Brahimi N, Bingen E, Elion J, Denamur E: The link between phylogeny and virulence in Escherichia coli extraintestinal infection. Infect Immun 1999, 67:546-553.

32. Boyd $E F$, Hartl $D L$ : Chromosomal regions specific to pathogenic isolates of Escherichia coli have a phylogenetically clustered distribution. J Bacteriol 1998, 180:1159-1165.

33. Patzer SI, Baquero MR, Bravo D, Moreno F, Hantke K: The colicin G, H and $x$ determinants encode microcins $M$ and $H 47$, which might utilize the catecholate siderophore receptors FepA, Cir, Fiu and IroN. Microbiology 2003, 149:2557-2570

34. Šmarda J, Šmajs D, Lhotová H, Dědičová D: Occurrence of strains producing specific antibacterial inhibitory agents in five genera of Enterobacteriaceae. Curr Microbiol 2007, 54:113-118.

35. Rijavec M, Budic M, Mrak P, Müller-Premru M, Podlesek Z, Zgur-Bertok D: Prevalence of ColE1-like plasmids and colicin K production among uropathogenic Escherichia coli strains and quantification of inhibitory activity of colicin K. Appl Environ Microbiol 2007, 73:1029-1032.

36. Šmajs D, Pilsl H, Braun V: Colicin U, a novel colicin produced by Shigella boydii. J Bacteriol 1997, 179:4919-4928.

37. Braude Al, Siemienski JS: The influence of bacteriocins on resistance to infection by gram-negative bacteria. II. Colicin action, transfer of colicinogeny, and transfer of antibiotic resistance in urinary infections. J Clin Invest 1968, 47:1763-1773.

38. Šmajs D, Karpathy SE, Šmarda J, Weinstock GM: Colicins produced by the Escherichia fergusonii strains closely resemble colicins encoded by Escherichia coli. FEMS Microbiol Lett 2002, 208:259-262.

39. Chumchalová J, Šmarda J: Human tumor cells are selectively inhibited by colicins. Folia Microbiol (Praha) 2003, 48:111-115.

40. Farkas-Himsley H, Cheung R: Bacterial proteinaceous products (bacteriocins) as cytotoxic agent of neoplasia. Cancer Res 1976, 36:3561-3567.

41. Šmarda J, Šmajs D, Horynová S: Incidence of lysogenic, colicinogenic and siderophore-producing strains among human non-pathogenic Escherichia coli. Folia Microbiol (Praha) 2006, 51:387-391.

42. Rozen S, Skaletsky HJ: Primer3 on the WWW for general users and for biologist programmers. In Bioinformatics Methods and Protocols: Methods in Molecular Biology. Edited by: Krawetz S, Misener S. Totowa, NJ: Humana Press; 2000:365-386.
43. Preacher KJ: Calculation for the chi-square test: An interactive calculation tool for chi-square tests of goodness of fit and independence [Computer software]. 2001 [http://www.quantpsy.org].

doi:10.1186/1471-2180-10-288

Cite this article as: Šmajs et al:: Bacteriocin synthesis in uropathogenic and commensal Escherichia coli: colicin E1 is a potential virulence factor. BMC Microbiology 2010 10:288.

\section{Submit your next manuscript to BioMed Central and take full advantage of:}

- Convenient online submission

- Thorough peer review

- No space constraints or color figure charges

- Immediate publication on acceptance

- Inclusion in PubMed, CAS, Scopus and Google Scholar

- Research which is freely available for redistribution

Submit your manuscript at www biomedcentral com/submit
Biomed Central 